\title{
Factor Model of Human Capital Accumulation in the Context of Global Challenges
}

\author{
${\text { Ekaterina } \text { Zharova }^{1 *} \text {, Nickolay Minaev }}^{1}$, and Olga Gevorgyan ${ }^{1}$ \\ ${ }^{1}$ Tomsk State University, Institute of economy and management, 36 Lenin Ave., Tomsk 634050, \\ Russian Federation
}

\begin{abstract}
The transition to the fourth industrial revolution and the digital economy leads to a new socio-economic formation. In the new society, the place and role of human capital in the system of factors that ensure the socioeconomic development of territories are being rethought. Human capital is becoming one of the key elements that ensure the sustainable development of territories and increase their global competitiveness. The increasing role of human capital creates a need to develop effective mechanisms for managing its accumulation and use, which requires systematic research of factors that affect this process. To solve this problem, the team of authors formed a factor model of the territory's human capital accumulation in the context of global challenges and responses to them. The generated model was developed in such a way as to reflect the system of factors, as well as the nature of their influence and relationship.
\end{abstract}

\section{Introduction}

The fourth technological revolution and digitalization of the economy determine the transition to a new socio-economic formation, which defines a new place and role of human capital. The formation of a new type of economy (the innovative, the knowledge-based), creates new conditions, in which the competitive advantage is on the side of territories that have not only the potential for scientific and technological development, but also a comparable stock of human capital. At the same time, for modern socio-economic systems, one of the key factors of development is the increase in the openness of the external environment of functioning. Increasing globalization and inter-country interaction activates the processes of capital movement (including human capital) both between countries and within countries [1]. As a result of increased mobility, there is a growing disparity in the amount of accumulated human capital of various territories, which in turn generate uneven socio-economic development of territories. This trend is particularly typical for the Russian Federation n. In the context of the described processes, the study of factors that affect the accumulation of human capital becomes relevant.

\section{Objects and methods of research}

* Corresponding author: yekaterina.zharova@mail.ru 
The category "human capital" as "... formed as a result of investment and accumulated by individuals stock of knowledge, skills and other qualities that, when used appropriately, generate a new value and revenue stream" [2], today it is a phenomenon well studied by foreign scientists and actively considered by domestic researchers. Thus, various aspects of human capital are currently considered, starting from the definition of its essential nature and structure, to the construction of complex econometric models that reflect the impact of human capital on the socio-economic development of the economies of countries and regions.

In the conditions of increasing influence of human capital on the socio-economic development of territories, as well as growth of disparities in its distribution, there is also a closer attention of scientists to the study of factors affecting its accumulation. However, it should be noted that when considering factors of human capital accumulation, researchers usually consider them separately. Thus, today the most actively studied issues of the impact of the educational system on human capital and developed approaches to its transformation. The need for transformation is due to changes in the requirements for knowledge, skills and abilities that a specialist must possess in the context of the formation of "Industry 4.0 " and the digital economy [3-6]. Heightened interest in the study of this factor is explained by the fact that the educational system, according to researchers, is a key element that ensures the reproduction of human capital. Much attention is also paid to the research of demographic processes that affect the final value of the human capital of territories, the causes of population migration, as well as demographic shifts caused by a decrease and increase in the birth rate, mortality and population size. Among other issues, there are a number of research articles devoted to assessing the impact on human capital of such factors as the level of development of social infrastructure, the level of public health, the labor market, the environmental factor, and others [7-11]. It should be noted that despite the variety of studies presented that reflect the impact of various factors on the accumulation of human capital, most of them do not contain a deep analysis, but are only a general description of a set of factors that do not take into account the existence of relationships between them.

Thus, we can conclude that despite numerous studies covering various factors that affect the process of human capital accumulation, today, a slight degree has been presented that reflects the complex impact of factors from the perspective of a systematic approach. As a result, the purpose of this research is to find, analyze and systematize factors that affect the accumulation of territory's human capital. The key difference between the study should be the consideration of factors as a system, rather than a set of individual elements, which will reflect the complex nature of their influence, as well as demonstrate their relationship with each other.

To achieve this goal, the study used such general-logical methods and ways as analysis, modeling and a systematic approach. The analysis allows us to consider the process of accumulation of human capital and identify individual factors that will be combined using modeling and a systematic approach into a factor model that reflects the nature of the impact of factors on the accumulation of human capital and their interdependence.

\section{Results and discussion}

Domestic researchers $(4,5,8)$ in their work identify different factors affecting human capital accumulation, however, in the framework of the presented research, we propose a new factor model authoring, which is a reflection of the factors with the system approach, and also contains a description of the nature and stages of their impact on territory's human capital accumulation (figure. 1).

Thus, at the first stage, external factors that arise at the global level and are not controlled by the territory begin to have a direct impact on human capital (arrow 1) and internal factors (arrow 2), prompting the territory to respond to global challenges. The second stage is 
adaptation the system of internal factors-responses to the impact of external factorschallenges and respond to them with the highest speed in order to strengthen or compensate for the positive or negative effects of external factors, respectively, which is also projected on human capital (arrow 3). The size of the territory's human capital depends on the speed and quality of adaptation of the system of territorial factors to global challenges and the efficiency of strategic decision-making at the territorial level. Due to the fact that the territory cannot immediately adapt to dynamically changing external factors, there is a time lag, which in some cases is of critical importance. Thus, the main task of territorial management is to analyze and forecast global processes in order to assess the readiness of the territory to respond to external factors, as well as continuous qualitative improvement of the system of internal factors.

\begin{tabular}{|c|c|}
\hline \multirow{8}{*}{$\begin{array}{c}\text { THE SYSTEM OF INTERNAL } \\
\text { (TERRITORIAL) FACTORS- } \\
\text { RESPONSES TO GLOBAL } \\
\text { CHALLENGES }\end{array}$} & Factor of territorial development of science \\
\hline & Factor of territorial technological equipment \\
\hline & Factor of the territorial educational system \\
\hline & Factor of the territorial labor market \\
\hline & Factor of territorial ecology \\
\hline & Factor of territorial security system \\
\hline & Factor of territorial infrastructure \\
\hline & Factor of the territorial health care system \\
\hline & $\sqrt[8]{3}$ \\
\hline HUMAN C & ITAL OF THE TERRITORY \\
\hline \multirow{8}{*}{$\begin{array}{c}\text { THE SYSTEM OF EXTERNAL } \\
\text { (GLOBAL) FACTORS - } \\
\text { CHALLENGES }\end{array}$} & $\begin{array}{l}\text { Factor of the processes of development of world's } \\
\text { basic science }\end{array}$ \\
\hline & Factor of introduction of advanced technologies \\
\hline & $\begin{array}{l}\text { Factor in the development of a global competitive } \\
\text { education market }\end{array}$ \\
\hline & $\begin{array}{l}\text { Factor of global transformations of the structure of } \\
\text { productive forces }\end{array}$ \\
\hline & Factor of global climate (ecological) processes \\
\hline & Global threat factor \\
\hline & Factor of transport infrastructure development \\
\hline & The factor of diversification of energy consumption \\
\hline
\end{tabular}

Fig. 1. Factor model of human capital accumulation [Authoring]

It should also be noted that the accumulated value of the territory's human capital, as well as its quality, largely determines the quality of the system of internal factors (arrow 4). This is due to the fact that the system of internal factors reflects the level of socio-economic development of the territory, which is significantly affected by human capital in modern conditions. Within the framework of the presented research, it is also necessary to disclose in more detail the content of the factors presented in the figure (tables 1,2).

Table 1. System of internal (territorial) factors-responses to global challenges

\begin{tabular}{|l|l|}
\hline \multicolumn{1}{|c|}{ Factor } & \multicolumn{1}{c|}{ Meaning } \\
\hline $\begin{array}{l}\text { Factor of territorial development of } \\
\text { science }\end{array}$ & $\begin{array}{l}\text { The level of science development that ensures the transfer } \\
\text { of knowledge and technologies for their wide application } \\
\text { in the relevant areas of socio-economic development of the } \\
\text { territory }\end{array}$ \\
\hline
\end{tabular}




\begin{tabular}{|l|l|}
\hline $\begin{array}{l}\text { Factor of territorial technological } \\
\text { equipment }\end{array}$ & $\begin{array}{l}\text { The level of technological equipment of the territory that } \\
\text { allows to apply the latest achievements of science and } \\
\text { technology in practice, as well as to fully realize the } \\
\text { potential of the territory's human capital }\end{array}$ \\
\hline $\begin{array}{l}\text { Factor of the territorial educational } \\
\text { system }\end{array}$ & $\begin{array}{l}\text { The level of development of the territorial educational } \\
\text { system that allows for continuous reproduction and } \\
\text { accumulation of human capital capable of applying modern } \\
\text { knowledge and technologies }\end{array}$ \\
\hline Factor of the territorial labor market & $\begin{array}{l}\text { The state of the territorial labor market, characterized by } \\
\text { indicators of employment, unemployment, average wages, } \\
\text { etc. }\end{array}$ \\
\hline Factor of territorial ecology & $\begin{array}{l}\text { The level of protection of the territory from anthropogenic } \\
\text { impact }\end{array}$ \\
\hline Factor of territorial infrastructure & $\begin{array}{l}\text { The level of development of the territorial security system } \\
\text { necessary to counteract new types of threats arising from } \\
\text { the development of technologies }\end{array}$ \\
\hline $\begin{array}{l}\text { Factor of the territorial health care } \\
\text { system }\end{array}$ & $\begin{array}{l}\text { Level of development of social, industrial, transport and } \\
\text { other types of infrastructure }\end{array}$ \\
$\begin{array}{l}\text { The level of development of the health care system that } \\
\text { allows using the achievements of modern science in order } \\
\text { to ensure the preservation of the territory's human capital }\end{array}$ \\
\hline
\end{tabular}

Table 2. System of external (global) factors - challenges

\begin{tabular}{|l|l|}
\hline \multicolumn{1}{|c|}{ Factor } & \multicolumn{1}{|c|}{ Meaning } \\
\hline $\begin{array}{l}\text { Factor of the processes of } \\
\text { development of world's basic science }\end{array}$ & $\begin{array}{l}\text { The processes of development of the world's basic science, } \\
\text { due to the need for breakthrough research aimed at the } \\
\text { accumulation of human capital (in the field of health, agro- } \\
\text { and water management, security, energy, etc.) }\end{array}$ \\
\hline $\begin{array}{l}\text { Factor of introduction of advanced } \\
\text { technologies }\end{array}$ & $\begin{array}{l}\text { Widespread introduction of advanced digital, intelligent } \\
\text { manufacturing technologies, use of robotic systems, new } \\
\text { materials and methods of construction, creation of } \\
\text { algorithms and systems for working with big data, } \\
\text { machine learning and AI technologies }\end{array}$ \\
\hline $\begin{array}{l}\text { Factor in the development of a global } \\
\text { competitive education market }\end{array}$ & $\begin{array}{l}\text { The level of development of the global competitive } \\
\text { education market, which causes high mobility of human } \\
\text { capital }\end{array}$ \\
\hline $\begin{array}{l}\text { Factor of global transformations of the } \\
\text { structure of productive forces }\end{array}$ & $\begin{array}{l}\text { Qualitative transformation of production forces, which is } \\
\text { carried out through the rapid development and } \\
\text { introduction of new technologies in all spheres of life and } \\
\text { activity of people and society, resulting in a change in the } \\
\text { role of people in the production process and changing the } \\
\text { structure of the global labor market }\end{array}$ \\
\hline $\begin{array}{l}\text { Factor of global climate (ecological) } \\
\text { processes }\end{array}$ & Global climate changes caused by man-made activities \\
\hline Global threat factor & $\begin{array}{l}\text { The emergence of new types of threats, including man- } \\
\text { made, biogenic, socio-cultural, cyber threats, and others. }\end{array}$ \\
\hline $\begin{array}{l}\text { Factor of transport infrastructure } \\
\text { development }\end{array}$ & $\begin{array}{l}\text { Ensuring global connectivity of territories through the } \\
\text { development of transport infrastructure, creation and } \\
\text { development of new modes of transport }\end{array}$ \\
\hline $\begin{array}{l}\text { The factor of diversification of energy } \\
\text { consumption }\end{array}$ & The need to switch to new fuels and energy \\
\hline
\end{tabular}

\section{Conclusion}


The analysis has shown that today the process of accumulation of human capital from the perspective of a systematic approach to the influence of various factors on it remains poorly understood. In this regard, one of the most significant conclusions is that the study was the first attempt to systematize and reflect the nature and stages of the impact of factor systems on the accumulation of human capital. It should be noted that the factor model is in a continuous dynamic state, due to changes in the nature and set of global challenges. In addition, it is important to emphasize that the significant role of the territory in responding to global challenges has been identified, which consists in the speed and quality of response to global challenges, depending on which the amount of accumulated human capital is formed. The obtained factor model is of practical significance for regional Executive authorities of the Russian Federation, since it can be used in the development of strategic planning documents aimed at long-term and sustainable development of regions.

\section{References}

1. O. Zaborovskaya Management of the regional economy's human capital in the conditions of intensification of interaction with the external environment, Journal of legal and economic research 4, 15-21 (2013)

2. S. Kurgansky The structure of human capital and its assessment at the macro level, Proceedings of the Irkutsk state Academy of Economics 6, 15-22 (2011)

3. R. Melnikov Assessment of the effectiveness of investments in higher and secondary vocational education in modern Russian conditions, Economic analysis: theory and practice 16, pp.1486-1507 (2017)

4. E. Shirinkina Assessment of the quality of education in the formation of human capital, Business. Education. Law. Bulletin of the Volgograd Institute of business 3, 138-143 (2016)

5. T. Klyachko, E. Semionova Contribution of education to the socio-economic development of Russian regions, Regional economy 14, 791-805 (2018)

6. G. Untura Estimation of Human Capital influence on economic Growth in Russian Regions under conditions of financial shortage, Spatial Economics 15, 107-131 (2019)

7. N. Boyko Social infrastructure and its impact on the formation of human capital in the territorial entities of the Russian Federation, Business. Education. Law. Bulletin of the Volgograd Institute of business 1, 148-154 (2015)

8. E. Prishlyak, S. Radko Research of factors influencing the formation of human capital in the Russian Federation, Management sciences 8, 94-105 (2018)

9. O. Potasheva Influence of external factors on the development of human capital, Drucker's Bulletin 9, 56-69 (2016)

10. A. Chul'dum The main factors of the human capiatl reproduction process in the innovativa economy 6, 366-373 (2019)

11. A. Sokolov The role of human capital in ensuring sustainable and balanced development of the territory, Scientific review. Series 1: Economics and law 4, 68-75 (2016) 